\title{
Impact of entrepreneurship policies on opportunity to startup
}

\author{
Ali Davari ${ }^{a^{*}}$ and Taraneh Farokhmanesh ${ }^{\mathrm{b}}$ \\ ${ }^{a}$ Assistant Professor, University of Tehran, Tehran, Iran \\ ${ }^{b} M A$ in Entrepreneurship, University of Tehran, Tehran, Iran

CHRONICLE A B T T A C T \\ Article history: \\ Received: February 1, 2016 \\ Received in revised format: April \\ 16,2017 \\ Accepted: June 10, 2017 \\ Available online: \\ June 12, 2017 \\ Keywords: \\ Entrepreneurship policy \\ Opportunity to startup

\begin{abstract}
During the previous decades, policy makers have formulated policies for developing entrepreneurship in different countries in order to decrease unemployment and poverty toward sustainable development. Some of these policies include encouraging people to be an entrepreneur, opportunity creation, educating new skills to entrepreneurs and so on. In recent years, an appropriate context has been formed for entrepreneurship development in Iran and some programs have been executed. So, formulating appropriate frameworks to guide Iranian government in this way is a necessity. This paper evaluates the impact of entrepreneurship policies on opportunity to startup in Iran. The results of path analysis indicate that supportive financial and nonfinancial actions influence positively on opportunity to startup. In addition, education and culture also influence positively on opportunity to startup. Finally, legislation also positively influ-
\end{abstract} \\ ences on opportunity to startup.
}

\section{Introduction}

Entrepreneurs have a key role in economic and social development. Developed countries experiences show that their development is the result of entrepreneurs endeavor. Entrepreneurship development leads to establishment of new companies, wealth creation, job creation, poverty decrease and finally economic \& social development (Ahmad \& Hoffmann, 2007; Koster \& Kumar 2008). Accordingly, entrepreneurship policies have been considered by governments in recent decades. These policies comprise education, managerial and financial supports, loans, awareness programs and so on (Lim et al., 2010)

In Iran, various reasons such as low productivity and slow economic growth have caused for uprising rate of unemployment as an economic and social problem. Therefore, the entrepreneurship can contribute to reduce the mentioned issues. Accordingly, the Iranian policymakers paid more attention to entrepreneurship in recent years and assessing the impact of entrepreneurship policies on opportunity to startup is a necessity. The concept of entrepreneurship policies is different from one country to another one. For instance, creation of a favorable economic environment to form and survival of entrepreneurial

\footnotetext{
* Corresponding author.

E-mail address: ali_davari@ut.ac.ir (A. Davari) 
firms have been emphasized in the United States. Policymakers formulate specific policies in order to increase the number of startups in various countries. Therefore, entrepreneurship policy frameworks and opportunity to startup will be reviewed in the next section.

\subsection{Global entrepreneurship monitor or GEM framework}

This framework uses broad entrepreneurship definition (Koster \& Kumar, 2008). Based on this framework the following three policies in social, political and cultural context are needed for developing entrepreneurial attitudes, activities, aspiration and finally national economic growth (GEM,2016)

- Basic requirements including institutions, infrastructure, macroeconomic stability, health and primary education.

- Efficiency enhancers including higher education \& training, goods market efficiency, labor market efficiency, financial market sophistication, technological readiness and market size.

- Innovation and entrepreneurship including entrepreneurial finance, public entrepreneurship programs, entrepreneurship education, $R \& D$ transfer, commercial, legal infrastructure for entrepreneurship and entry regulation (GEM,2016)

\subsection{The OECD Framework}

This framework includes determinants to improve opportunities, skills and motivation in order to develop entrepreneurship development.

- Regulation and law for reducing administrative barriers, tax,

- Availability of domestic and foreign market,

- Financing, business angles and venture capital,

- Education and training for entrepreneurial companies,

- Cultural programs and entrepreneurial events.

These policy areas will improve total Performance of Entrepreneurship such as business creation and development (OECD, 2016).

\subsection{Hall Framework}

This framework shows the affecting factors of entrepreneurship development as a process, including: economic inputs and resources such as venture capital availability and skilled human resource. Technology and infrastructure availability lead to entrepreneurial results such as new business formation, patents issues and new goods and services. However, the amount of entrepreneurial results generated from a given amount of economic inputs depends primarily on public policies (e.g. tax, business regulations, legal/judicial system, economic freedom) under which entrepreneurs operate. This framework shows that increasing entrepreneurship can be accomplished by increasing the inputs or improving public policies for entrepreneurs (Hall \& Sobel, 2006). Public policies comprise institutions that can be formal or informal. Formal institutions are including economic, political and judicial rules that affect the opportunities (Nkya, 2003).

\subsection{Canadian Atlantic Entrepreneurship Development Framework}

The framework attends to three dimensions (motivation, opportunity and skills) towards entrepreneurship development. According to this framework, the rate of entrepreneurship in a community increases, if people care to entrepreneurship as a possible option and are willing to pursue it (motivation) have enough knowledge, skills and ability to pursue it (skills) and adequate support to set up a business 
(opportunities) such as accessibility to information, consultancy services, financial resources and incentives. Based on this framework entrepreneurship development policies should formulate indicators that affect these three dimensions (Lundstrom \& Stevenson, 2006).

\subsection{Entrepreneurship framework based on countries comparative studies}

Fields of entrepreneurship policies studies in different countries ${ }^{1}$ have proven that there were two kinds of entrepreneurship goals or effects: Create a more positive attitude towards entrepreneurship in society (cultural promotion) and remove barriers to start a business (elimination of obstacles). Entrepreneurship policies can be classified into six groups regarding to these effects (Lundstrom \& Stevenson, 2006).

Entrepreneurship promotion: these policies try to increase awareness of society about entrepreneurship and promote a positive attitude towards entrepreneurship which include TV programs, introduction of entrepreneurial role models and support of conferences related to entrepreneurship.

Entrepreneurship education: these policies insist on entrepreneurship in educational system like entrepreneurship curriculum, industry \& university interface.

Improving the environment for entry and growth of businesses: these policies include business laws improvement through facilitating the business establishment processes, exit and entry laws improvement such as reforming laws in relation to competition, bankruptcy, intellectual property, tax and labor.

Financial Supports: these policies increase financial supports such as loan payment to SMEs, lower interest rates, loan guarantees and assisting the SMEs to access more financial information.

Start-up Business Supports: increasing the quality and quantity of business supports include consulting services, technical services \& training.

Target Group Strategies: these policies try to increase the business establishment by innovative individuals in groups that are less considered in the society such as youth, women, religious minorities, the unemployed and technology entrepreneurs. Increasing entrepreneurship in target groups have two purposes 1)reduce barriers to minority participation and 2)improve access to information, financial resources, technical assistance, consulting, network administration and public services to equalize opportunities.

\subsection{Kuzilwa Entrepreneurship Development Framework}

Three main factors affect the entrepreneurship development:

1- Contextual factors e.g. profitable opportunities and economic freedom.

2- Institutional factors e.g. accessibility to financial resources, consultancy and legal frameworks.

3- Personal factors e.g. education and work experience.

These three factors together affect the entrepreneurial activities in a country (Kuzilwa, 2005).

\subsection{UNCTAD Framework}

In this study, entrepreneurship policies are distinguished from general policies (macro economy stability, labor markets, local infrastructure and so on). Entrepreneurship policies comprise increasing access to finance (loans, stock market \& venture capital), facilitating entry and exit (lower administrative burden, improving failure law, award programs) and supportive programs (SMEs development, awareness, minorities support) (UNCTAD, 2005).

\subsection{Peng and Lee Framework}

${ }^{1}$ Australia, Taiwan, United States, Canada, Finland, Ireland, Spain, Netherlands, Sweden and England 
According to Lee et al. (2013) policies that show the entrepreneurial endeavor in a country, can be divided in two policy areas as follows,

Maximize gains: these policies motivate people for entrepreneurship and help business establishment.

These policies remove the barriers that are in the beginning of entrepreneurship process:

$\checkmark$ Government policies toward reducing industry entry barriers.

$\checkmark$ Strong enforcement of antitrust regulations.

$\checkmark$ Government deregulation policies.

Minimizing loses: these policies help the bankrupt entrepreneurs for minimizing losses:

$\checkmark$ Improving bankruptcy regulations for entrepreneurs.

$\checkmark$ Encourage entrepreneurship development by risk reduction associated with failing firms and industries (Golden et al., 2003).

\subsection{Entrepreneurship policy in opportunity to startup}

Few papers have presented a clear meaning and concept of opportunity. Entrepreneurial opportunities are influenced by institutional environment and entrepreneurial policies. These opportunities contribute establishing new business creation, startups, high growth firms and competitive advantages (Pinho, 2016). Entrepreneurship plays an important role in solving social, economic and environmental problems (Hall et al., 2010). Entrepreneurship policies result to more opportunities that finally affect better economic performance.

\section{Conceptual Framework}

In this section, entrepreneurship policies frameworks that were explained above are summarized in Table 1 and the proposed framework is formulated.

Table 1

Summaries of entrepreneurship policies frameworks

\begin{tabular}{|c|c|}
\hline Framework & Main Policies \\
\hline GEM & basic requirements, Efficiency enhancers, Innovation \\
\hline The OECD & regulation, market availability, financing, cultural programs, education and training \\
\hline Hall Framework & economic inputs and resources, public policies and entrepreneurial outcomes \\
\hline $\begin{array}{l}\text { Canadian Atlantic Entrepre- } \\
\text { neurship Development } \\
\text { Framework }\end{array}$ & $\begin{array}{l}\text { Entrepreneurship development policies towards motivation, opportunity and skills im- } \\
\text { provement }\end{array}$ \\
\hline $\begin{array}{c}\text { Entrepreneurship Framework } \\
\text { based on Comparative Stud- } \\
\text { ies of Countries }\end{array}$ & $\begin{array}{l}\text { Promotion, education, improving the environment, financial \& business supports, tar- } \\
\text { get group strategies }\end{array}$ \\
\hline $\begin{array}{l}\text { Kuzilwa Entrepreneurship } \\
\text { Development Framework }\end{array}$ & contextual factors, institutional factors and personal factors \\
\hline UNCTAD Framework & $\begin{array}{l}\text { increasing access to finance, facilitating entry and exit and government support pro- } \\
\text { grams }\end{array}$ \\
\hline Lee's framework & Maximize gains and minimizing loses \\
\hline
\end{tabular}


Based on the following framework shown in Fig. 1, entrepreneurship development in a society guided by governmental or public policies leads to entrepreneurship results or direct results such as job creation, poverty reduction and opportunity to startup.

Entrepreneurship policies include three dimensions including: regulation, education \& culture and Support that influence opportunities windows to startup.

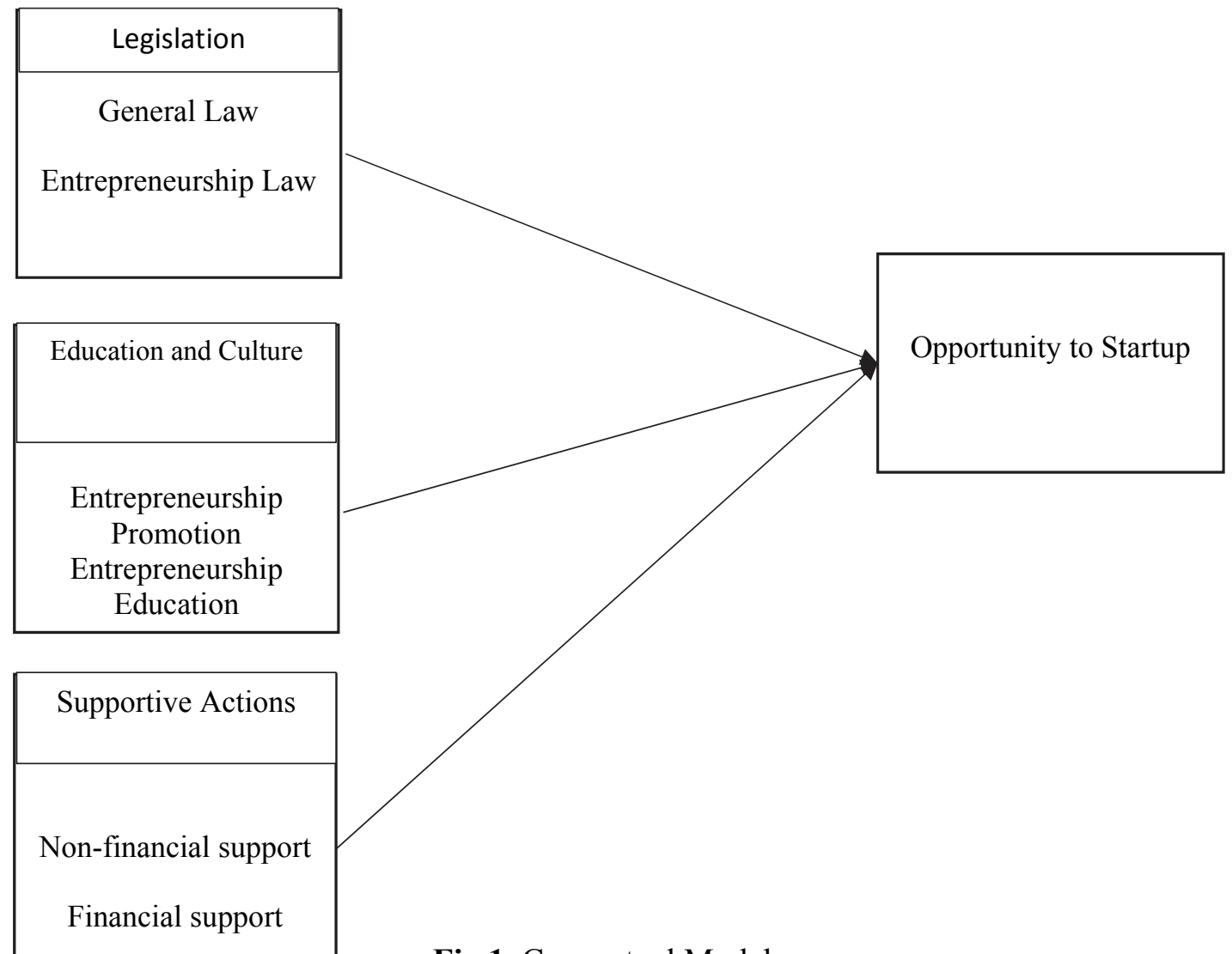

Fig.1. Conceptual Model

Regulation: government by formulating or changing laws improves climate or context for entrepreneurship development. These policies include:

A) General laws that have indirect effect on entrepreneurship include tax, competition, bankruptcy laws and so on.

B) Entrepreneurship laws that have direct impact on entrepreneurship development comprise facilitating entry and exit of businesses.

Education and Cultural Capacity Building: These policies try to motivate people and improve their skills and attitudes include

A) Entrepreneurship education such as entrepreneurial training in society.

B) Entrepreneurship promotion like giving information and introducing role models to the society.

Support: When somebody establishes a business, he/she needs support to prevent bankruptcy. These supports are:

A) Financial supports like credit and loan.

B) Non-financial supports like technical and managerial consultancy. 
Opportunity to Startup (Dependent Variable): Entrepreneurial opportunities are influenced by institutional environment and entrepreneurial policies and business environment. This opportunities contribute establishing new business creation, startups, high growth firms and competitive advantages (Pinho, 2016).

\section{Research Methodology}

This is an applied and descriptive correlational study. The necessary data was collected using a questionnaire. Random sampling and Cochran's method was used to calculate the sample size, a number of 81 questionnaires were completed by national experts of entrpreneurship and small businesses. The current paper examined two aspects of entrpreneurship policies (regulation, education and culture, Support) as independent variables and opportunity to startup of as the dependent variable in a questionnaire using a five point Likert scale.

Discriminant Validity was used to determine the validity of the questionare, using Average Variance Extracted (AVE) and Convergent Validity, as well. Table 2 shows that research variables are appropriate for divergent validity. Composite reliability and Cronbach's alpha reliability coefficient swere used to assess the reliability, the coefficients specified in Table2 indicate the reliability of research. Structural equation modeling technique was used for data analysis and Smart PLS software on hypotheses testing, given the research type and the need to assess the impact of independent variables on the dependent variable. It should be noted that the convergent validity results showed that the Root Mean-Variance extracted for each construct structures is more compared to its correlation with other structures. Thus, the questionnaire has required validity.

\section{Table 2}

Questionnaire Validity and Reliability

\begin{tabular}{cccc}
\hline Construct & Composite Reliability & Cronbach's Alpha & AVE \\
\hline Regulation & 0.84 & 0.89 & 0.59 \\
Education and Culture & 0.90 & 0.91 & 0.52 \\
Support & 0.94 & 0.85 & 0.66 \\
Opportunity to Startup & 0.88 & 0.80 & 0.72 \\
\hline
\end{tabular}

\subsection{Data Analyzing}

Confirmatory factor analysis was used to investigate the relationship between the observed variables (indicators and questionnaire items) with latent variables (dependent and independent variables). Hypothesis test was accomplished using path analysis. Table 3 depicts hypotheses test results.

\section{Table 3}

Hypothesis test

\begin{tabular}{|c|c|c|c|c|c|}
\hline & Hypothesis & $\begin{array}{c}\text { Path } \\
\text { coefficient }\end{array}$ & \multicolumn{2}{|c|}{ T-value } & Result \\
\hline 1 & $\begin{array}{l}\text { Regulation has an impact on opportunity } \\
\text { to startup. }\end{array}$ & 0.41 & accept & 12.77 & Hypothesis is supported \\
\hline 2 & $\begin{array}{l}\text { Education and culture has an impact on } \\
\text { opportunity to startup. }\end{array}$ & 0.35 & accept & 9.22 & Hypothesis is supported \\
\hline 3 & $\begin{array}{l}\text { Support has an impact on opportunity to } \\
\text { startup. }\end{array}$ & 0.48 & accept & 8.89 & Hypothesis is supported \\
\hline
\end{tabular}

PLS path analysis software was used to test the hypothesis. Generally, research path analysis model was significant. The PLS model Goodness of Fit of the model was obtained through the square root of the product of the average cumulative index of the mean square of the correlation coefficients between structures. In this research, given that GOF is calculated to be 0.48 and is greater than 0.36 ; so we can say that the model is a perfect fit. 
- Hypothesis 1) tested the impact of regulation has an impact on opportunity to startup. The path coefficients show regulation affect opportunity to startup by $0.41(\mathrm{t}>1.96)$.

- Hypothesis 2) tested the impact of education and culture has an impact on opportunity to startup. The path coefficients show education and culture affect opportunity to startup by $0.35(\mathrm{t}>1.96)$.

- Hypothesis 3) tested the impact of support has an impact on opportunity to startup. The path coefficients show support affect opportunity to startup by $0.48(\mathrm{t}>1.96)$.

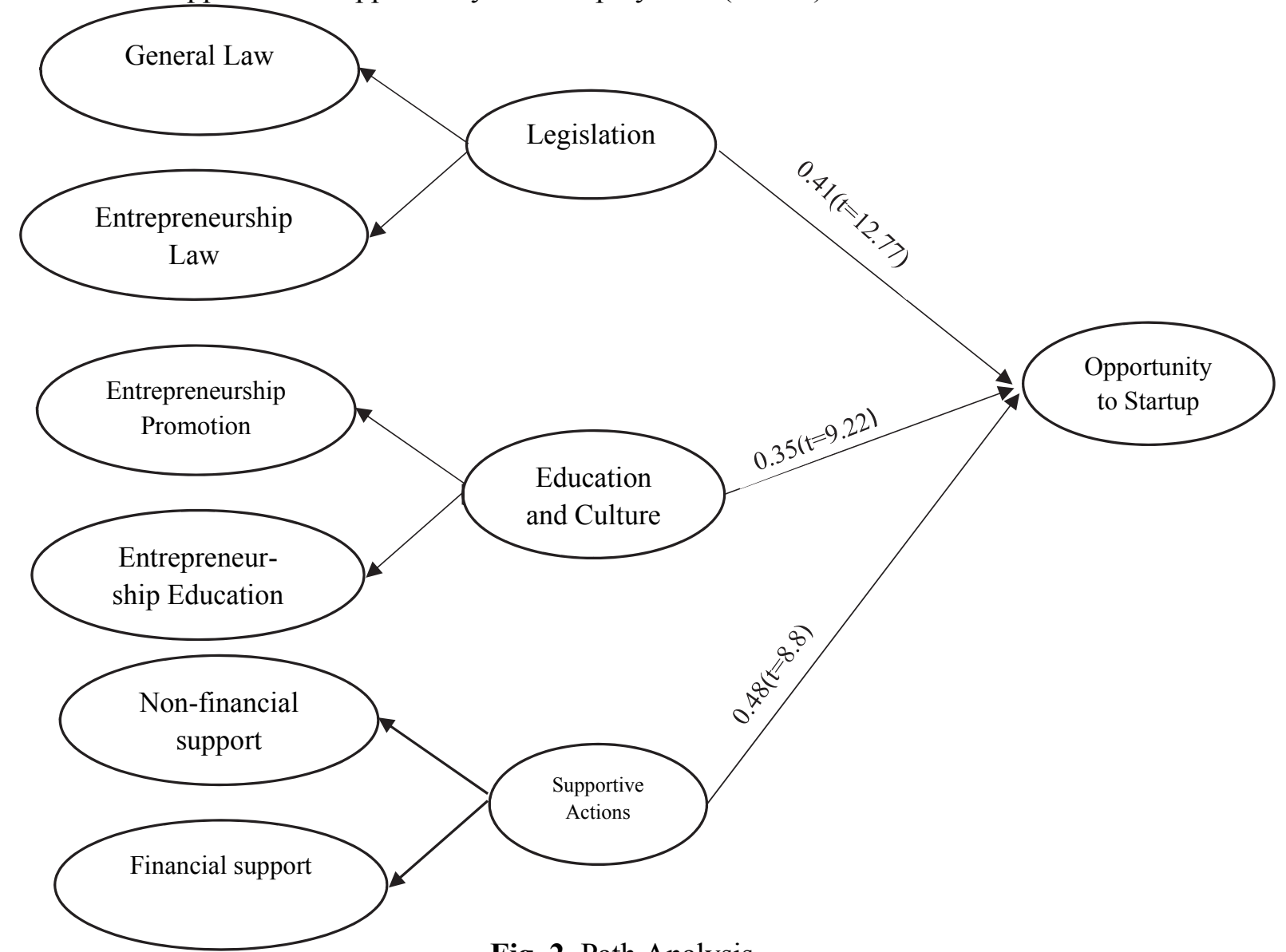

Fig. 2. Path Analysis

\section{Conclusion and Suggestions}

This research has assessed the impact of entrepreneurship policies on opportunity to startup.

The data gathering tools were questionnaire based on national experts' opinions. We have developed three hypotheses. Based on the results 1) Regulation 2) Education and culture 3) Support have positive impacts on opportunity to startup. According to the results, the following points have been suggested.

- Evaluation should be considered before, during and after implementation of entrepreneurship policies to assess effectiveness.

- Privatization of government activities: Considering that one of the main goals of privatization is increasing innovation, entrepreneurship.

- Improving business environment: improving the business environment is a prerequisite for the entrepreneurship development. Recently the business environment has been proposed as one of the main components of entrepreneurship development frameworks.

- More Supports for entrepreneurs: many small businesses and entrepreneurs need more financial and non-financial supports in early stages to avoid bankruptcy. First 42 months (4 years) is considered as the best time period contribution. It means entrepreneurs need at least 4 years financial and non-financial supports. 
- Execution is more important than regulations: Sometimes it is observed that laws are changed but improper implementation may create more troubles for entrepreneurs.

\section{Acknowledgement}

The authors would like to thank the anonymous referees for constructive comments on earlier version of this paper.

\section{References}

Ahmad, N., \& Hoffmann, A. (2008). A framework for addressing and measuring entrepreneurship. OECD.

GEM. (2016) Global Entrepreneurship Monitor available at: http://gemconsortium.org

Golden, W., Higgins, E., \& Lee, S. H. (2003). National innovation systems and entrepreneurship. Golden, E. Higgins, SH Lee. Ireland: Centre of Innovation and Structural Change.

Hall, J. K., Daneke, G. A., \& Lenox, M. J. (2010). Sustainable development and entrepreneurship: Past contributions and future directions. Journal of Business Venturing, 25(5), 439-448.

Hall, J. C., \& Sobel, R. S. (2006). Public policy and entrepreneurship. Center for Applied Economics Technical Report, 06-0717.

Koster, S., \& Rai, S. K. (2008). Entrepreneurship and economic development in a developing country: a case study of India. The Journal of Entrepreneurship, 17(2), 117-137.

Kuzilwa, J. A. (2005). The Role of Credit for Small Business Success A Study of the National Entrepreneurship Development Fund in Tanzania. Journal of entrepreneurship, 14(2), 131-161.

Lim, D. S., Morse, E. A., Mitchell, R. K., \& Seawright, K. K. (2010). Institutional environment and entrepreneurial cognitions: A comparative business systems perspective. Entrepreneurship Theory and Practice, 34(3), 491-516.

Lundstrom, A., \& Stevenson, L. A. (2006). Entrepreneurship policy: Theory and practice, Vol. 9, Springer Science \& Business Media.

Nkya, E. J. (2003). Institutional barriers to small-scale business development: a need for flexibility in Tanzanian tax and regulatory systems. The Journal of Entrepreneurship, 12(1), 43-73.

OECD (2016). Entrepreneurship at a glance 2016, available at: http://www.oecd-ilibrary.org

Lee, S. H., Peng, M. W., \& Song, S. (2013). Governments, entrepreneurs, and positive externalities: A real options perspective. European Management Journal, 31(4), 333-347.

Pinho, J. C. (2016). Institutional theory and global entrepreneurship: exploring differences between factor-versus innovation-driven countries. Journal of International Entrepreneurship.

UNCTAD (2005). Entrepreneurship and Economic Development. United Nations Conference On Trade And Development.

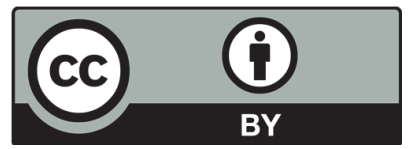

(C) 2017 by the authors; licensee Growing Science, Canada. This is an open access article distributed under the terms and conditions of the Creative Commons Attribution (CC-BY) license (http://creativecommons.org/licenses/by/4.0/). 